\title{
Psychological Factor Affecting English Speaking Performance for the English Learners in Indonesia
}

\author{
Youssouf Haidara \\ Unilingual English, University of Bamako, Mali
}

Copyright $(2016$ by authors, all rights reserved. Authors agree that this article remains permanently open access under the terms of the Creative Commons Attribution License 4.0 International License

\begin{abstract}
In every learning situation or environment, human psychology plays a significant role. English speaking is a language skill that is highly affected by human psychology. This research aimed at describing the psychological factor that affects negatively the English speaking performance for the English learners in Indonesia. A descriptive qualitative design was used to conduct this research. The research was consisted of theoretical review, field notes, observations, and unstructured interviews. The participants were 20 students. The data were analyzed using the interactive analysis technique developed by Miles and Huberman (1994). The results of the research reveal that the psychological factor truly affects negatively the students' English speaking performance. Although most of the students think that they have good level of English vocabulary and grammar, they are insecure while speaking English. Most of the problems were (1) Fear of making mistakes (2) Feeling shy (3) Feeling hesitated (4) lack of confidence while speaking English. Finally, some suggestions expected to be significant remedies to overcome the problem were proposed by the researcher.
\end{abstract}

Keywords English as a Foreign Language in Indonesia, Speaking Skill, Psychological Factor

\section{Introduction}

In this era of globalization, knowledge of a foreign language serves students well in the interconnected world, it opens the door to job opportunities in the global economy and makes more media accessible, enriching public discussion of current issues. At present, the language that dominates internationally is certainly English. According to Kachru and Smith [201]:

"In the era of globalization and rapid diffusion of knowledge, all the nations are aware of the need to prepare their citizens to perform in ways that would ensure their prosperity and eminence in the world. In order to be competitive, they have to be able to function well in multinational industrial enterprises, international trade, diplomacy, and scientific technological areas of expertise. They have to be innovative and contribute to the knowledge-based of the world. In order to achieve these goals, they need to be able to utilize the most widely used medium, English."

In reference to the evolution of human mind, it is clear that English has become the most widespread language in the world, used by more peoples for more purposes than any other language on Earth. English is now an international language, spoken in many countries both as a native and as a second or foreign language. It is taught in the schools in almost every country on this earth.

The most influential model of the spread of English is Braj Kachru's model of World Englishes. In this model, the diffusion of English is captured in terms of three Concentric Circles of the language: The Inner Circle, the Outer Circle, and the Expanding Circle (Kachru and Smith, 2008). [4]. The Inner Circle represents countries such as the United Kingdom, the United States, Australia, New Zealand, where English is widely used as a first language; the Outer Circle represents countries such as India, Nigeria, Bangladesh, Singapura, Malaysia, where English is institutionalized; and the Expanding Circle represents countries where English plays no historical or governmental role, but where it is nevertheless widely used as a medium of international communication. This includes much of the rest of the world's population, most of European, Asian or African countries such as Mali, Egypt, China, Russia, Japan, Korea, and Indonesia.

In Indonesia, English is considered as the primary foreign language which is given more importance than any of the other foreign languages being taught in the country. This is in line with the statement presented by Lauder [9-20], explaining that the expanding or extending circle refers to nations which recognize the importance of English as an international language, but which were not colonized by the countries of inner circle, and which have not given English any special official status. In these countries, English is taught as a foreign language. Indonesia belongs to this 
group.For more convincing idea, Junaidi Mistar by Braine [71] also explains that in order to equip Indonesians with an ability to communicate at the international level, English is the first foreign language officially taught to students from junior secondary school. This implies that English language cannot be separated from Indonesian educational system and Indonesian students daily life. Indonesian children learn English since the fourth grade of elementary school as a compulsory subject. After the senior high school, many of the Indonesian undergraduate students keep on majoring in English language education at one of the Indonesian prominent Universities.

Forthe more, English has become part of students' everyday activities in Indonesia; most of them feel very proud once they are able to speak the English language well. Unfortunately, most of the above mentioned students always show increased levels of anxieties when speaking English for the oral communicative purposes is concerned. Those levels of anxieties are remarkable due to the factors such as being called by the teachers to respond orally to questions or having to present something in front of the class. Therefore, the problems mentioned above truly require an investigation.

Speaking is one of the productive skills that enables us to convey or to express something in a spoken language. It is the ability to interact orally with others by sharing with them one's point of views and feelings in different situations that take place in the real time. According to Akhyak and Indramawan [18], improving the English speaking competence is very important for the Indonesian students where it is known that Speaking is extremely need to give the big contribution to students to perform their communication skill better.

\section{Theoretical Review}

\subsection{English as a Foreign Language in Indonesia}

Indonesia, a large archipelago with so many islands and also with different spread of developments, is one of the countries where English is used as a foreign language. According to Lauder [9], the use of English in Indonesia has developed in the context of post-colonial educational competency building, and more recently the need to support development, in particular its role in state education. In addition, it is widely recognized that English is important for Indonesia and the reason most frequently put forward for this is that English is a global or international language. In Indonesia educational system, English is a compulsory subject to be taught in all schools.

The linguistic situations and conditions in Indonesia are very complex to such an extent that the students' English speaking performance can hardly escape from being affected. Indonesia is a country with many vernaculars and also with various dialects from a great number of ethnic groups. This is in line with the statement presented by Lauder [13] explaining that language policy in Indonesia has to contend with a highly multicultural and multilingual society. English, its status, and its role or function in the functioning of the nation and in education in particular has to be seen against the backdrop of where it takes a place in the third or three main categories, Bahasa Indonesia, the regional vernaculars, and foreign languages.

\subsection{Nature of Speaking Skill}

Speaking skill is labelled oral production and is certainly one of the skills students need to learn in their language development. This research focused on the speaking skill because the mastery of speaking skill in learning any language including English is a priority for many second or foreign language learners. This is in line with the point presented by Richards [19] stating that learners often evaluate their success in language learning as well as the effectiveness of their English course on the basis of how much they feel they have improved in their spoken language proficiency. That is to say, speaking skill is one of the linguistics skills of language development that should be mastered by the target language learners.

One of the macro skills of English teaching and learning is speaking. It is not easy to define what is meant by terms such as speaking skill since it has been defined in various ways in different disciplines. Its definition varies in nature as the scholars have different perspectives in defining it. For instance, one definition says that in language use situations, when people speak, it is not the case that they simply open their mouths and speak the words and sentences. When people speak, they are doing so in a cultural context, they are speaking to another person or persons (perhaps friends, a teacher or a tester) who bring with them a relative degree of status and power and they are doing so in order to meet the purpose required of the interaction, which may be a conversation, or a task that needs completing, McKay [179]. This implies that know a language and be able to speak it is something that is different as we have to deal with the contextual use of the language also.

To emphasize that speaking skill is a cornerstone in the issue of second or foreign language teaching and learning process, Luoma [ix] also elicits that the ability to speak in a foreign language is at the very heart of what it means to be able to use a foreign language. Our personality, our self image, our knowledge of the world and our ability to reason and express our thoughts are all reflected in our spoken performance in a foreign language. Therefore, speaking skill needs to be mastered by the English learners. The researcher focuses this research on the English speaking performance because the mastery of the English speaking skill is a priority for many foreign language learners, and what is worth to be known is that most of the English learners usually measure their ability of the English language based on how well they can speak it.

\section{Research Method}

A descriptive qualitative research method was used for 
this research. According to Creswell [16], the qualitative research is best suited to address a research problem in which you do not know the variables and need to explore. The literature might yield little information about the phenomenon of study, and you need to learn more from participants through exploration. To him [206], in qualitative inquiry, the intent is not to generalize to a population, but to develop an in-depth exploration of a central phenomenon. Thus, to best understand this phenomenon, the qualitative researcher purposefully or intentionally selects individuals and sites. In reference to the above explanation presented by Creswell, the research purposefully selected 20 students in Applied Linguistics field at the Graduate School of Yogyakarta State University to act as the research participants.According to McNiff [76], there are various traditional methods in data collection procedure like personal field notes, audio tape recording, diaries, interviews and discussion, videotapes, recording, questionnaires, documentary evidence, slide, tape, photography.

To collect the data from those 20 students mentioned above, some classroom observations were done first. Creswell [213] explains the term observation as the process of gathering open-ended, firsthand information by observing people and places at a research site. In reference to this point, the students were observed duringtheir presentations of their findings in front of the class as well as when they were interacting with each other trying to use English which they rarely do. Most of the case, they speak using Bahasa Indonesiaor Bahasa Jawa. They also switch code which they mix with Bahasa Indonesia(Indonesian) or with Bahasa Jawa (Javanese language). These classroom observations have given the researcher the opportunity to collect open-ended and firsthand information about the question under study.

In addition to the data gained from the observations, the researcher also invited 10 out of 20 students to have interviews. The interviews were unstructured interviews. Punch [144] believes that the interview is the most prominent data collection tool in qualitative research. It is a very good way of accessing people's perceptions, meanings, and definitions of situations and constructions of reality. It is also one of the most powerful ways we have of understanding others. Because of some students' availability, all the 20 participants have not been interviewed, only 10 out 20 participants took part of the interview. The participants were asked about their difficulty in speaking English, about why they always switch the code, about why they prepare their findings and their PowerPoint in English then present them using Bahasa Indonesia, and about why they feel insecure or worried when using English to communicate. In reference to the answers of the different queries mentioned above, great amount of data related to the psychological factor that affects the students' English speaking practices were gained.

It is previously mentioned that great data were gained from two sources of data collection, observation and unstructured interview. To prove the trustworthiness of the data, the researcher compared and cross-checked the field notes, the data from the observation, and the data from the interview to each other.

The interactive analysis technique developed by Miles and Huberman [9] was implemented to analyze the collected data. The interactive analysis consists of three interrelated components namely reduction of data, display of data, and conclusion. The data reduction was done by selecting, determining the focus, simplifying, summarizing and modifying the form of raw data from the field. In this step, the researcher dealt with sharpening, separating, and finally with limiting the data to those that were only related to the psychological factor that negatively affects students' speaking performance. The next step was the displays of data during which the researcher arranged and organized the data just after the reducing (displays of data). The reasons for reducing and displaying data were to assist in drawing some conclusions. Finally, it is concluded by systematically describing the results in the section Finding and Discussion.

Universitas Negeri Yogyakarta (UNY) is the Indonesian name for Yogyakarta State University (YSU). It is the former Education and Teaching Training Institute of Yogyakarta (IKIP Yogyakarta). Then, it has been established and became one of the most prestigious institutes of education in Indonesia. After it got its wider mandate to open non educational program in 1999, its name was changed to Yogyakarta State University (YSU).

\section{Finding}

\subsection{Description}

The data of this research were collected from 20 students of Applied Linguistics at Graduate School of Yogyakarta State University. The objective of this research was to describe the psychological factor affecting students' English speaking performance in Indonesia. The data were gathered by two different means, which are observation and interview.

In reference to the results from the observation sheets and the Interview, it is obvious that the students' English speaking performance is negatively affected which was manifested by their own psychology. The results also show that the students have been learning English for many years as they have good level in English grammar and English vocabulary but most of them used to be speechless when using English for communicative purposes is concerned. Most of the psychological factor affecting students' English speaking performance were manifested by things such as fear of making mistakes, shyness, hesitation, and lack of confidence.

\subsection{Discussion}

The research reveals that students' English speaking performance is negatively affected by psychological factor as they have good level in English grammar and vocabulary but are not confident while speaking English is concerned. English teachers should be aware of the fact that students 
lack confidence to speak English.

In reference to the data from the observations, the results have shown the remarks such as (1) When the students have to do some assignments or group discussions then to present the findings in front of the class or by using PowerPoint, they do the assignments and prepare the PowerPoint using English, but most of them do the presentation using Indonesian or mixing English with Indonesian. In one hand, if the presentation is done using Indonesian, the class is active and students ask so many questions about the topic being presented. In other hand, if the presentation is done using English, the students can understand, but none or very few of them ask questions about the topic being presented. (2) Sometimes, most of the students who start using English to answer to questions or to ask questions to lecturer end up by using Indonesian owing to multiple hesitations.

In reference to the remarks mentioned above during the classroom observations, ten of the students were found available to give their opinions about the remarks being done. All of the ten students admit the remarks to be true among them. Then they agreed that their main psychological barrier in speaking English was due to a lack of confidence. In fact, since the students do not feel able to speak English in a natural way, and since they are always thinking abouthow to pronounce correctly a word or how to use the correct grammar structures, they said that it is difficult to feel confident. The second, and somehow connected, is making mistakes, because most of them think that people may laugh at them if they mispronounce some words as in Indonesia is referred to "Takut salah"; then they prefer not to interact in English until they know for sure that they are not making any mistake.In addition, some students' own perception of the language can be negative and can appear as a reluctance in speaking English or barrier. For example, many students expressed that speaking English outside the classroom is a style of people who just like to show off since using English makes most students feel uncomfortable while interacting with people. Another conception is that students think that language is complicated and difficult, so they already put a barrier since they don't make any effort and they tell themselves that they do not have the ability to learn that language. All that formerly mentioned are widely observable on those English learners.

To answer the questions on what have been noticed during the classroom observations about students' reluctance from speaking English, the students complain about problems such as being anxious, being nervous, being worried of making mistakes, feeling shy, and feeling frustrated while performing in English for the communicative purposes. Those various complaints from the interview were cross-check with the field notes from the observation from which the researcher realized that the reluctance of the students from speaking English is caused by their psychology. The data gained from the students' perspective in terms of causes of psychological factor negatively affect their English speaking performance are the fear of making mistakes, the shyness, the hesitation, and the lack of confidence. Most of them are afraid not to be laughed and mocked by their friends in case of mispronouncing some words.

Regarding to fear of making mistakes and shyness, some students believe, not to have problem if they just have to talk to each other using English, but they said to feel shy if they make mistakes while talking to lecturers or when presenting in front of the class. This implies that the students' fear of making mistakes is also due to the shyness they feel when they fail to produce accurate English in front of their lecturers or in front of the class. Two students confirmed that the fact their feeling shy is part of their cultural background as shy persons.

Regarding to hesitation and lack of confidence, according to the students, lack of confidence is something that happens to them when they are talking to someone who's English speaking is more superior to theirs like lecturers or native English speakers and so on. To them, if it happens that the person does not understand something about what they are talking about, they can suddenly see themselves in a deep hesitation without being able to distinguish correct from wrong about what they have to say. Most of those students think that their English speaking is bad since they do not sound like native English speakers. As a matter of fact, they keep silent until they are convinced for sure that what they have to say is really correct and well pronounced as a native English speaker' s English.

\subsection{Suggestions}

In reference to human capacity, nothing can be done to change the past, but anything we do today can affect the future. This research focuses on psychological factor as one of the factors that hinder students from practicing their English speaking performance in Indonesia because the researcher believes that one of the biggest problems among EFL students today is the psychological one. Psychology is the number one key to success for most EFL students in their English speaking performance. Most of the EFL students who learned English for many years, most of them have difficulties to use the language to speak, whereas when we analyze, we come to know that most of them have good level of vocabulary or grammar. Therefore, it is not only the lack of grammar or vocabulary, but it is also a matter of psychology, their beliefs, their confidence, and their strong feelings in themselves. Most of those EFL students have weak motivation; they never develop confidence in themselves. For example, the researcher himself has been learned English for many years but was still felt insecure using English to communicate. Fortunately, the researcher has discovered some very useful videos on YouTube, namely Effortless English provided by an English lecturer, Mr. A.J. Hoge. Watching those videos from Mr. A.J. Hoge, the researcher understood that one of the factors that can hinder EFL students to speak English is in our own mind, our psychology, and then he felt more and more confident in using English to speak. Today the researcher is proud to give motivation to other students in terms of English speaking performance. 
In reference to the researcher's own experience concerning the question under study, in order to overcome the problems mentioned above, students are encouraged to: (1) stop bearing in mind that the English language is difficult to understand, (2) stop worrying much about what other persons see their spoken English, (3) stop underestimating themselves, and (4) stop thinking much about mistakes. For the more, they should practice and use English as much as they can without caring much about mistakes. They should know and understand that no one is perfect, perfection is impossible and they should not have to always think of mistakes as bad or negative things. This is in line with the statement presented by Sousa [59] explaining that people learn from their mistakes, so they should think of them as useful and positive.

\section{Conclusions}

Referring to the results of the research, it can be concluded that the psychological factor does negatively affect students' English speaking performance. Most of the problems that the students were complaining to be the causes of their reluctance from speaking English were: (1) Fear of making mistakes. (2) Feeling shy. (3) Feeling hesitated. (4) Lack of confidence while speaking English.

First, we mentioned that for some students, they only feel shy if it happens that they make mistakes while presenting something in front of the class or while interacting with lecturers using English. We also mentioned that according to two of the students, the fact of their feeling shy is part of their cultural background as shy persons. Second, as far as lack of confidence was concerned while speaking English, for the students, it happens to them to feel insecure to speak English when they have to talk to someone who's English speaking is more superior to theirs like lecturers or native English speakers which is a fact that makes students feel hesitated about what to say is correct or wrong. Finally, it is understood that all the factors being mentioned were the psychological ones hindering students from speaking English.

In order to overcome the problems, some suggestions were proposed by the researcher. The researcher has referred to his own experience as an EFL learner to give those suggestions expected to be significant remedies to those students who learn English as a foreign language. According to the researcher, psychology is the number one key to success for most EFL students in their English speaking performance since most of them have good level of English grammar and English vocabulary.

It is suggested that in order to overcome the shyness, fear of making mistakes, hesitation, lack of confidence while speaking English, the students are encouraged to: (1) stop bearing in mind that the English language is difficult to understand, (2) stop worrying much about what other persons see their spoken English, (3) stop underestimating themselves, and (4) stop thinking much about mistakes. For the more, they should practice and use English as much as they can without caring much about mistakes. They should know and understand that no one is perfect, perfection is impossible and they should not have to always think of mistakes as bad or negative things because people learn from the mistakes they make.

\section{REFERENCES}

[1] Braine. G (2005). Teaching English to the world: History, Curriculum, and Practice. New Jersey: Lawrence Erlbaum Associates.

[2] Creswell, John W. (2012). Educational Research: Planning, Conducting, and evaluating quantitative and qualitative Research $\left(4^{\text {th }}\right.$ ed.). Nebraska: Pearson Education.

[3] Indramawan, A., \& Dr. Akhyak. (2013). Improving the Students' English Speaking Competence through Storytelling (Study in Pangeran Diponegoro Islamic College (STAI) of Nganjuk, East Java, Indonesia). International Journal of Language and Literature, Vol. 1 No. 2.

[4] Kachru. Y \& Smith L. E (2008). Cultures, Contexts, and world Englishes. New York: Taylor \& Francis.

[5] Lauder. A. (2008). The status and Function of the English in Indonesia: A review of key factors. Indonesia: Makara, Sosial Humaniora. Vol 12, No. 1, Juli 2008: 9-20.

[6] Luoma. S. (2004). Assessing Speaking. Cambridge: Cambridge University Press.

[7] McKay. P. (2006). Assessing Young Language Learners. Cambridge: Cambridge University Press.

[8] Miles, B. M \& Huberman, A. M. (1994). Qualitative data analysis. London: International Educational and Professional Publisher.

[9] McNiff. J. (1998). Action research: Principles and practice. London: Macmillan.

[10] Punch. K. F. (2009). Introduction to Research Methods in Education. Thousand Oaks, California: SAGE.

[11] Richards. J. C. (2008). Teaching Listening and Speaking. From Theory to Practice. New York: Cambridge University Press.

[12] Sousa. D. A (2011). How the ELL Brain learns. New Delhi: SAGE. 